\title{
PENGEMBANGAN PENDIDIKAN MULTIKULTURAL MELALUI DIALOG ANTAR UMAT BERAGAMA PERSPEKTIF AL-QUR'AN DAN HADITS
}

\author{
Roib Santoso ${ }^{1}$, Fahrur Roji ${ }^{2}$, M. Farid Zaini ${ }^{2}$ \\ ${ }^{1}$ Universitas Yudharta Pasuruan, ${ }^{2}$ Universitas Sunan Giri Surabaya \\ roibsantoso@gmail.com,mohamad_faridzaini@yahoo.co.id
}

\begin{abstract}
Abstrak : Pendidikan multikultural dipandang penting untuk mengubah paradigma seseorang bahkan masyarakat yang monokultural menjadi multikultural, Pendidikan multikultural disampaikan dan dimusyawarahkan dengan antar umat beragama (non muslim). Ide-ide pendidikan multikultural selain diinternalisasikan dalam dunia pendidikan, juga dilakukan melalui dialog antar umat beragama dalam bentuk FKUB. FKUB sampai saat ini dipandang efektif dan efisien untuk menyampaikan ide-ide pendidikan multikultural karena keterwakilan dari berbagai kelompok dan golongan tersebut. Penyampaian ide-ide pendidikan multikultural disampaikan dengan pola komunikasi yang diajarkan dalam al-Qur'an. Dalam kontek al-Qur'an dan Hadits, pendidikan multikultural menguraikan ragam bentuk komunikasi dengan qaulan ma'rufan (berbicara dengan kata-kata yang lembut) qaulan sadiidan (berbicara dengan tutur kata yang benar), qaulan balighan (menasehati secara rahasia dan menasehati dengan kata-kata yang bisa membekas di hatinya), qaulan kariman (berkata yang menenteramkan hati yang disesuaikan dengan keadaan, kebiasaan dan zaman), qaulan maysuuran (perkataan yang baik agar tidak mengecewakan karena belum mendapat yang diharapkan), dan qaulan layyinan yaitu perkataan yang lembut dan beradab, tidak membual, tidak keras ucapannya dan tidak kasar sikapnya). Pola komunikasi ini menjadi dasar dalam implementasi pendidikan multikultural melalui dialog antar umat beragama, sehingga kerukunan dan saling menghormati antar umat beragama dapat terwujud dengan baik
\end{abstract}

Keyword : Pendidikan multicultural, dialog umat beragama, Quran dan hadits

\section{A. Latar Belakang}

Bangsa yang multikultural adalah bangsa yang kelompok-kelompok etnik atau budaya (ethnic and cultural groups) yang ada dapat hidup berdampingan secara damai dalam prinsip co existensi yang ditandai oleh kesediaan untuk menghormati 
budaya lain¹. Karena Perbedaan adalah sebuah keniscayaan, firman Allah yang artinya sebagai berikut:

Jikalau Tuhanmu menghendaki, tentu Dia menjadikan manusia umat yang satu, tetapi mereka senantiasa berselisih pendapat, Kecuali orang-orang yang diberi rahmat oleh Tubanmu. dan untuk Itulah Allah menciptakan mereka. kalimat Tubanmu (keputusan-Nya) telah ditetapkan: Sesunggubnya aku akan memenubi neraka Jahannam dengan jin dan manusia (yang durbaka) semuanya. (QS. Huud: 118-119) Al Qur'an Surat Huud ayat 118-119 ini diperkuat dengan surat al Hujurat ayat 13 yang artinya:

Wahai manusia! Sungguh, Kami telah menciptakan kamu dari seorang laki-laki dan seorang perempuan, kemudian Kami jadikan kamu berbangsa-bangsa dan bersukusuku agar kamu saling mengenal.

Ungkapan tetapi mereka senantiasa berselisih pendapat dalam [Huud: 118-119] menunjukkan bahwa Allah tidak menghendaki manusia satu pandangan, dan penggunaan bentuk kata kerja yang menunjuk pada masa mendatang (al-fil almudhâri ${ }^{\prime}$ mengindikasikan bahwa perbedaan di antara manusia akan terus terjadi. Karena itu pemaksaan dalam berdakwah kepada mereka yang berbeda pandangan, baik dalam satu agama maupun dengan penganut agama lain, tidak sejalan dengan semangat menghargai perbedaan yang menjadi tuntunan al-Qur'an².

Sedangkan surat al Hujurat ayat 13 memberitahukan bahwa Allah menciptakan manusia dari asal dan jenis yang satu yakni Adam dan Hawa'. Allah menyebarkan dari keduanya laki-laki dan perempuan yang banyak dan memisahkan serta menjadikan mereka berbangsa-bangsa dan bersuku-suku agar mereka saling mengenal sehingga mereka bisa saling menolong, saling membantu dan saling mewarisi serta memenuhi hak kerabat. Walaupun demikian, orang yang paling mulia di antara mereka adalah orang yang paling takwa, yakni mereka yang paling banyak ketaatannya kepada Allah dan meninggalkan maksiat, bukan yang paling banyak kerabat dan kaumnya dan bukan yang paling mulia nasabnya. Dalam ayat ini terdapat dalil bahwa mengetahui nasab adalah disyariatkan, karena Allah menjadikan mereka berbangsa-bangsa dan bersuku-suku adalah untuk itu³.

\footnotetext{
${ }^{1}$ Atho Mudzhar, Meretas Wawasan dan Praksis Kerukunan Umat Beragama di Indonesia,dalam Bingkai Masyarakat Multikultural, Jakarta: Badan Litbang Agama dan Diklat Keagamaan, 2005. hlm. 3

${ }^{2}$ Muchlis M. Hanafi, “Kosep Al-Wasathiyyah Dalam Islam,” Harmoni 8 (2009): 51.

${ }^{3}$ Abu Yahya Marwan Bin Musa, Tafsir Al Qur'an Hidayatul Insan Jilid IV (www.tafsir.web.id, n.d.).
} 
QS. Huud: 118-119 dan al Hujurat ayat 13 tersebut menggambarkan kondisi Indonesia yang sangat beraneka ragam secara budaya, etnis, bahasa, maupun agama. Berbagai etnis berbicara dengan dialek yang berbeda, bahkan Penduduk Indonesia juga terdiri dari enam agama besar yaitu Islam, Kristen, Katolik, Buddha, Hindu dan Khong Hu Cu merupakan pengikat berdasarkan dogma sesuai dengan ajaran agama masing-masing ${ }^{4}$. Mayoritas penganut Islam tersebar di Sumatera, Jawa, Madura, Kalimantan, Sulawesi, Lombok, Sumbawa dan pulaupulau di Maluku Utara. Penganut Kristen Protestan mayoritas tersebar di Irian Jaya, Katolik di Pulau Plores, Timor Timur, dan mayoritas Hindu tersebar di Pulau Bali5.

Keragaman budaya tersebar di seluruh nusantara tersebut berpengaruh terhadap tingkah laku, sikap, pola pikir manusia sehingga manusia memiliki caracara (usage), kebiasaan (folk. ways), aturan-aturan (mores) bahkan adat istiadat (customs) yang berbeda satu sama lain. Bila perbedaan itu tidak dapat dipahami dengan baik dan diterima dengan bijaksana, maka konflik akan mudah terjadi di masyarakat ${ }^{6}$. Keragaman budaya ini pernah memercikkan konflik di Bangil (1997), penyebabnya adalah arogansi pihak keamanan, yang menimbulkan kemarahan massa yang baru saja menunaikan sholat Jumat berujung pada perusakan gereja, sesuatu yang hampir sama dengan banyak kejadian di tempat lain. Pada perusakan gereja di Pasuruan (1992) disebabkan oleh penghinaan seorang pendeta terhadap Islam. Sedangkan rencana perusakan gereja di Batu, terdapat kesamaan faktor pendorong, yaitu pelecehan terhadap al-Quran dan Islam ${ }^{7}$. Yang tak kalah menarik perhatian adalah Kasus berkenaan dengan pendirian umat beribadah, sebagian kalangan umat kristiani merasa sulit dalam mendirikan rumah ibadat di wilayah Indonesia bagian Barat. Kesulitan serupa juga dihadapi umat Muslim di wilayah Indonesia bagian Timur, sebagai contoh Kasus Masjid Al-Muhajirin Komplek Brimob Abepura dan Kasus Masjid Al-Mawaddah Kota Distrik Sentani ${ }^{8}$. Masalah

\footnotetext{
${ }^{4}$ Rusdi Muchtar, "Peran Jihad Dalam Menanamkan Nilai-Nilai Keagamaan" 8 (2009): 10. ${ }^{5} \mathrm{H}$ Mursyid Ali, Pemetaan Kehidupan Beragama Di Berbagai Daerah Di Indonesia, I. (Jakarta: CV. Prasasti, 2009).

${ }^{6}$ Farida Hanum dan Sisca Rahmadona, "Implementasi Model Pembelajaran Multikultural Di Sekolah Dasar Di Propinsi Daerah Istimewa Yogyakarta," Artikel Multikultural-Stranas, no. 2 (2009): 1-17.

${ }^{7}$ Endang Turmudzi, “Masalah Kerukunan Umat Beragama,” Harmoni 10 (2011): 516.

${ }^{8}$ Ibnu Hasan Muchtar, "Dinamika Hubungan Antarumat Beragama Di Kota Dan Kabupaten Jayapura Papua," Harmoni 10 (2011): 627.
} 
hubungan Islam dan Kristen yang tidak serasi ini tidak saja terjadi di Pasuruan saja tetapi hampir di seluruh Propinsi di Indonesia, bahkan juga terjadi di negeranegara Barat. Di Denmark terjadi pelecehan terhadap Nabi Muhammad SAW. Demikian pula di Belanda dan Amerika. Dalam tahun 2010, seorang pendeta mengajak umat Kristen Amerika untuk membakar al-Quran, karena dianggap mengandung ajaran-ajaran kekerasan ${ }^{9}$. Belum lupa tentang kasus konflik sunnisyi'ah di Madura dengan kekerasan terhadap golongan syi'ah di Sampang Madura yang diikuti dengan pertikaian sampai menewaskan beberapa orang dan pengusiran warga syi'ah ${ }^{10}$, muncul peristiwa pembakaran Masjid di Kabupaten Tolikara oleh umat Nasrani saat umat Islam Karubaga Kabupaten Tolikara hendak menjalankan shalat Idul Fitri ${ }^{11}$. Tidak lama kemudian terjadi peristiwa pembakaran Gereja oleh masyarakat muslim di Aceh Singkil12.

Beberapa kasus tersebut sangat menguras energi, merugikan materi dan bahkan mengorbankan jiwa serta keharmonisan antar sesama masyarakat indonesia ${ }^{13}$. Konflik terjadi selain sebab dari keragaman budaya, bisa juga terjadi akibat paradigma pendidikan baik formal maupun informal yang mendorong rasa saling menghormati, mengikis rasa perbedaan dan menemukan persamaan masih belum terwujud di beberapa negara tersebut. Apalagi ditambah dengan keengganan untuk belajar dari tradisi agama lain untuk saling mengenal lebih dekat. Keengganan semacam ini sering berujung stigma dan prejudice terhadap agama lain, sehingga memperlebar jurang perbedaan ${ }^{14}$.

Penyebab persoalan-persoalan di muka, bisa juga disebabkan soal pemahaman agama sebagian masyarakat yang masih rendah, sehingga mudah terprovokasi. Walaupun masyarakat Indonesia memiliki pegangan hidup dan keyakinan pada agama masing-masing, namun pegangan hidup dan keyakinannya

\footnotetext{
${ }^{9}$ Puslitbang Kehidupan Keagamaan Departemen Agama RI, "Dinamika Beragama Dalam Pergumulan Sosial Budaya,” Harmoni X, no. 1 (2011): 1-740. h. 516

${ }^{10} \mathrm{http} / /$ www.suarapembaruan.com/home/inilah-kronologis-kekerasan-warga-syiah-disampang/23865 diakses 1112016

${ }^{11} \mathrm{http}$ ://nasional.republika.co.id/berita/nasional/daerah/15/07/17/nrmprs-ini-kronologipembakaran-masjid-di-tolikara diakses 1012016

12 http://news.detik.com/berita/3043725/begini-awal-cerita-peristiwa-pembakaran-rumah-ibadahdi-aceh-singkil diakses 1112016

${ }^{13}$ dkk Tasnim Muhammad, "Implementasi Nilai-Nilai Multikultural Dalam Pendidikan Di Program Studi Pendidikan Bahasa Arab (PBA) Fakultas Tarbiyah Dan Bahasa IAIN Surakarta," JIAH 2 (2013).

14 Ibid.
} 
itu belum secara utuh dipahami apalagi dipraktekkan ${ }^{15}$. Persoalan kemiskinan dan keterbelakangan juga berpeluang besar untuk menjadikan masyarakat memiliki sikap, mental, bahkan budaya kemiskinan. Kemiskinan dan keterbelakangan pendidikan telah menjadi musuh yang nyaris tak terlawan yang selalu mengintai untuk menghancurkan kehidupan bangsa. Akibat kemiskinan, anak-anak usia sekolah kehilangan hak untuk memperoleh pendidikan setinggi-tingginya, atau bahkan ada yang terpaksa tidak bersekolah. Lebih dari itu, kualitas pendidikan yang rendah, persoalan di balik Ujian Nasional hingga maraknya perguruan tinggi swasta berkualitas sangat meragukan adalah contoh persoalan yang ada di balik kualitas pendidikan Indonesia ${ }^{16}$. Hal ini menunjukkan bahwa nilai-nilai multikultural masih belum dipahami dan dinternalisasi secara komprehensif oleh masyarakat Indonesia.

Dari sinilah perlu adanya terobosan yang bisa mengikis segala persoalan yang bisa menimbulkan pelbagai kasus tersebut, diantaranya adalah terobosan pendidikan multikultural. Pendidikan multikultural dipandang penting untuk mengubah paradigma seseorang bahkan masyarakat yang monokultural menjadi multikultural. Namun, tidak berhenti di situ saja, tetapi dimusyawarahkan dengan antar umat beragama (non muslim).

Terkait pendidikan multikultural dalam dunia pendidikan telah tertuang dalam Pasal 4 UU N0. 20 Tahun 2003 tentang Sistem Pendidikan Nasional. Dalam UU itu menggambarkan tujuan utama dari pendidikan multikultural yakni untuk menanamkan sikap simpati, respek, apresiasi, empati, terbuka dan toleran terhadap penganut agama dan budaya yang berbeda.

Pendidikan multikultural adalah suatu gerakan pembaharuan dan proses untuk menciptakan lingkungan pendidikan yang setara untuk seluruh siswa Sebagai sebuah gerakan pembaharuan, istilah pendidikan multikultural masih dipandang asing bagi masyarakat umum, bahkan penafsiran terhadap definisi maupun pengertian pendidikan multikultural juga masih diperdebatkan di

\footnotetext{
${ }^{15}$ Fauziyah, "Potret Kerukunan Hidup Umat Beragama Di Kabupaten Bondowoso Jawa Timur," Harmoni 2011 (n.d.). 648

${ }^{16}$ Abd A'la, "Pembumian Jihad Dalam Konteks Indonesia Kekinian, Pengentasan Masyarakat Dari Kemiskinan Dan Keterelakangan," Harmoni 8 (2009).
} 
kalangan pakar pendidikan ${ }^{17}$. Pendidikan multikultural menawarkan alternatif melalui penerapan strategi dan konsep pendidikan yang berbasis pada pemanfaatan keragaman yang ada di masyarakat, khususnya yang ada pada siswa seperti keragaman etnis, budaya, bahasa, agama, status sosial, gender, kemampuan, umur dan ras. Strategi pendidikan ini tidak hanya bertujuan agar supaya siswa mudah mempelajari pelajaran yang dipelajarinya, akan tetapi juga untuk meningkatkan kesadaran mereka agar selalu berperilaku humanis, pluralis, dan demokratis ${ }^{18}$. Pendidikan multikultural juga menawarkan ide, gerakan, pembaharuan pendidikan dan proses pendidikan yang tujuan utamanya adalah untuk mengubah struktur lembaga pendidikan supaya siswa baik pria maupun wanita, siswa berkebutuhan khusus, dan siswa yang merupakan anggota dari kelompok ras, etnis, dan kultur yang bermacam-macam itu akan memiliki kesempatan yang sama untuk mencapai prestasi akademis di sekolah ${ }^{19}$.

Sikap saling menghargai, toleransi, mampu hidup bersama dalam keragaman adalah tujuan dari multikulturalisme, yang dapat dimiliki setiap insan melalui pendidikan multikultural20.

Dari paparan tersebut, maka dalam paper ini akan mengkaji konsep pendidikan multikultural dalam perspektif al-Qur'an dan Hadits dan pengembangan pendidikan multikultural melalui dialog antar umat beragama perspektif al-qur'an dan hadits.

\section{B. Metode}

Penulisan ini dimaksudkan untuk mengumpulkan, mengkaji, dan mendalami pengembangan pendidikan multikultural melalui dialog antar umat beragama dalam persepektif al-Qur'an dan Hadits, dengan literatur seperti al-Qur'an, Hadits, kitab-kitab klasik dan tulisan-tulisan terkait seperti artikel, buku dan jurnal.

\footnotetext{
${ }^{17}$ Akhmad Hidayatullah Al Arifin, "Implementasi Pendidikan Multikultural Dalam Praksis Pendidikan Di Indonesia," Jurnal Pembangunan Pendidikan: Fondasi dan Aplikasi 1, no. 1 (2012): 72-82.

${ }^{18}$ Farida Hanum dan Sisca Rahmadona, "Implementasi Model Pembelajaran Multikultural Di Sekolah Dasar Di Propinsi Daerah Istimewa Yogyakarta."

${ }^{19}$ James A. Banks and Cherry A. McGee Banks, "Multicultural Education Issues and Perspectives. 3rd Ed. Needham Heights, MA: Allyn and Bacon," Connecticut State Department of Education, last modified 1997, ttp://www.sde.ct.gov/sde/cwp/view.asp?a.

${ }^{20}$ Farida Hanum dan Sisca Rahmadona, "Implementasi Model Pembelajaran Multikultural Di Sekolah Dasar Di Propinsi Daerah Istimewa Yogyakarta."
} 
Penelitian ini menggunakan pendekatan library research dengan content analysis. library research dimaksudkan untuk menelaah naskah, dokumen, arsip dan buku-buku yang berhubungan langsung dengan masalah yang dibahas. Hal ini dilakukan untuk kontruksi ide dan koridor dalam upaya untuk menemukan dan memverifikasi data-data terkait. Sedangkan content analysis menggunakan pendapat Burhan yang mendefinisikan analisis isi sebagai teknik penelitian untuk membuat inferensi-inferensi yang dapat ditiru (replictable), dan sahih data dengan memperhatikan konteksnya. Analisis isi berhubungan dengan komunikasi atau isi komunikasi ${ }^{21}$.

Dalam analisis data, menggunakan analisis deskriptif yaitu usaha untuk mengumpulkan dan menyusun suatu data, kemudian dilakukan analisis terhadap data tersebut. Data yang dikumpulkan adalah berupa kata-kata, gambar, dan bukan angka-angka dan yang dikumpulkan berkemungkinan menjadi kunci terhadap apa yang sudah diteliti22.

\section{Pembahasan}

\section{Pendidikan Multikultural}

Al Qur'an menjelaskan bahwa anak adalah anugerah dan generasi penerus. Kamus Besar Bahasa Indonesia Mendefinisikan anugerah adalah pemberian dari pihak atas kepada pihak bawah, misal karunia dari tuhan ${ }^{23}$.

Definisi anugerah di dalam bahasa Indonesia ini harmonis dengan definisi di dalam bahasa Inggris. Definisi di dalam bahasa Inggris ini diambil dari bahasa asli (Yunani) yaitu "Charis" yang berarti "Free gift" (pemberian cuma-cuma) ${ }^{24}$. Mengenai anugerah ini, al Qur'an menyebutkan pada surat al Isra' ayat 24, surat Maryam ayat 5 dan ayat 49, dan surat asy Syu'ara ayat 133.

a). Surat al isra' ayat 24 yang artinya:

\footnotetext{
${ }^{21}$ Burhan Bungin, Metodologi Penelitian Kualitatif Aktualisasi Ragam Varian Kontemporer (Jakarta: PT. Rajagrafindo Persada, 2007).

${ }^{22}$ Winarno Surachman, Pengantar Penelitian Ilmiah: Dasar, Metode (Tarsita, 1990).

${ }^{23}$ Tim Penyusun Kamus Bahasa Indonesia, Kamus Besar Bahasa Indonesia (Jakarta: Pusat Bahasa Departemen Pendidikan Nasional, 2008).

${ }^{24} \mathrm{http} / / /$ kebenaranbagidunia.org/anugerah-alla, Definisi ini berdasarkan konkordansi Yunani Inggris karangan J.B. Smith halaman 372, 5385 diakses 3012016
} 
Dan rendahkanlah dirimu terhadap keduanya dengan penuh kasih sayang dan ucapkanlah, "Wahai Tuhanku! Sayangilah keduanya sebagaimana mereka berdua telah mendidik aku pada waktu kecil

Dari ayat ini dapat dipahami, bahwa jika pendidikan yang diberikan banyak, maka semakin bertambah pula haknya. Oleh karena itu, orang yang mendidik seseorang dalam urusan agama dan dunianya dengan pendidikan yang baik selain kedua orang tuanya, maka dia memiliki hak terhadap orang yang dididik. Orang yang dididik perlu mendoakan kebaikan kepadanya, karena melalui pendidikan darinya, ia memperoleh banyak pengetahuan dan pengalaman ${ }^{25}$. Jangan sampai kita memperdengarkan kata-kata buruk kepada orang tua, berkatalah dengan lemah lembut, baik, sopan santun,, disertai pemulyaan dan penghormatan. Bahkan sampai mereka wafat, kita harus mendo'akannya, karena surga berada di telapak kaki ibu²6.

b). Surat maryam ayat 5 yang artimya:

Dan sungguh, aku khawatir terhadap mawaliku sepeninggalku, padahal istriku seorang yang mandul, maka anugerahilah aku seorang anak dari sisi$\mathrm{Mu}$,

Surat maryam ayat 5 berisi tentang kekhawatiran Zakariya terhadap mawalli yakni orang-orang yang akan mengendalikan dan melanjutkan urusannya sepeninggalnya, yang dikhawatirkan ialah kalau mereka tidak dapat melaksanakan urusan itu dengan baik, karena tidak seorangpun diantara mereka yang dapat dipercayainya, oleh sebab itu dia meminta dianugerahi anak ${ }^{27}$. Jika mereka melakukan tindakan buruk kepada manusia sepeninggalnya. Maka ia meminta anak kepada Alloh untuk menjadi Nabi sepeninggalnya agar ia bisa mendidik dan memimpin mereka dengan kenabiannya sesuai wahyu ${ }^{28}$. Hal ini menunjukkan perhatian beliau kepada kaumnya, dan permintaan agar dianugerahi anak untuk

${ }^{25}$ Abu Yahya Marwan Bin Musa, Tafsir Al Qur'an Hidayatul Insan Jilid II (www.tafsir.web.id, n.d.). h. 370

${ }^{26}$ Abdullah bin Muhammad bin Abdurahman bin Ishaq Al-Sheikh, Tafsir Ibnu Katsir Jilid 5, ed. M. Yusuf Harun MA, I. (Bogor: Pustaka Imam asy Syafi'i, 2003). Juz 15 h. 153

${ }^{27}$ Naf'an Akhun, AL QUR'AN Digital 2.1 (http://www.alqur'an-digital.com, 2007).

${ }^{28}$ Al-Sheikh, Tafsir Ibnu Katsir Jilid 5. Juz 16 h 311 
maslahat agama, agar agama ini tidak hilang. Beliau melihat bahwa selain beliau tidak cocok terhadap imamah fid din, dan ketika itu hanya rumah beliau yang paling terkenal tentang kebaikan agamanya, oleh karenanya beliau meminta kepada Allah agar dianugerahkan seorang anak yang akan menegakkan agama-nya setelah beliau wafat ${ }^{29}$.

c). Surat Maryam ayat 49 yang artinya:

Maka ketika dia (Ibrahim) sudah menjauhkan diri dari mereka dan dari apa yang mereka sembah selain Allah, Kami anugerahkan kepadanya Ishak dan Ya'qub. Dan masing-masing Kami angkat menjadi Nabi.

Oleh karena meninggalkan kampung halaman, keluarga dan kaumnya adalah sesuatu yang paling berat bagi seseorang, dan Nabi Ibrahim meninggalkan semua itu karena Allah, maka Allah menggantinya dengan yang lebih baik darinya, Allah menganugerahkan kepadanya seorang anak, yaitu Ishak, dan Ya'kub ${ }^{30}$. Alloh menjadikan untuknya keturunan dan anak cucunya sebagai Nabi yang namanya ditetapkan Alloh dalam hidupnya ${ }^{31}$.

d). Asy Syu'ara ayat 133 yang artinya:

Dia (Allah) telah menganugerahkan kepadamu hewan ternak dan anak-anak.

Yakni Dia memperbanyak harta dan keturunan kamu. Nabi Hud 'alaihis salam mengingatkan mereka nikmat-nikmat-Nya, dan selanjutnya mengingatkan mereka terhadap azab Allah 'Azza wa Jalla 32 .

Dari paparan beberapa ayat al Qur'an dan tafsir di muka, dapat disimpulkan bahwa anak adalah anugerah dari Allah SW'T yang harus dirawat dan dididik karena anak merupakan penerus perjuangan menegakkan kalimat Allah.

Secara harfiah Pengertian pendidikan adalah proses, cara, atau perbuatan mendidik. Pendidikan berasal dari kata dasar didik yang berarti memelihara dan

${ }^{29}$ Musa, Tafsir Al Qur'an Hidayatul Insan Jilid II. h. 434

${ }^{30}$ Ibid. h. 445

${ }^{31}$ Al-Sheikh, Tafsir Ibnu Katsir Jilid 5. Juz 16 h. 339

${ }^{32}$ Abu Yahya Marwan Bin Musa, “Tafsir Al Qur'an Hidayatul Insan Jilid III" (www.tafsir.web.id, n.d.). h. 168 
memberi akhlak dan kecerdasan pikiran ${ }^{33}$. Pendapat lain mengartikan Pendidikan adalah proses pengubahan sikap dan tata laku seseorang atau kelompok orang dalam usaha mendewasakan manusia melalui upaya pengajaran dan pelatihan ${ }^{34}$. Sedangkan menurut Undang-Undang No. 20 Tahun 2003 mengartikan pendidikan sebagai usaha sadar dan terencana untuk mewujudkan suasana belajar dan proses pembelajaran agar peserta didik secara aktif dapat mengembangkan potensi dirinya untuk memiliki kekuatan spiritual keagamaan, pengendalian diri, kepribadian, kecerdasan, akhlak mulia, serta keterampilan yang diperlukan dirinya dan masyarakat ${ }^{35}$. Dari beberapa definisi tersebut dapat disimpulkan bahwa pendidikan adalah proses pengubahan sikap dan tata laku seseorang atau kelompok orang dalam usaha mendewasakan manusia melalui upaya pengajaran dan pelatihan agar peserta didik secara aktif dapat mengembangkan potensi dirinya untuk memiliki kekuatan spiritual keagamaan, pengendalian diri, kepribadian, kecerdasan, akhlak mulia, serta keterampilan yang diperlukan dirinya dan masyarakat.

Sebelum membahas pendidikan multikultural, Islam mempunyai definisi sendiri, menurut sayyid Quthb pendidikan Islam adalah sistem pendidikan yang menekankan pada pola pendidikan yang menyeluruh dan mampu menyentuh seluruh potensi yang dimiliki peserta didik dan aspek kehidupan manusia ${ }^{36}$. Namun pendidikan multikultural mempunyai definisi tersendiri, walaupun para ahli berbeda-beda dalam mengutarakan definisi pendidikan multikultural seperti berikut:

Multicultural education is a set of strategies and materials in U.S. education that were developed to assist teachers when responding to the many issues created by the rapidly changing demographics of their students ${ }^{37}$.

Multicultural education is a progressive approach for transforming education that bolistically critiques and responds to discriminatory policies and practices in education ${ }^{38}$.

\footnotetext{
${ }^{33}$ Tim Penyusun Kamus Bahasa Indonesia, Kamus Besar Bahasa Indonesia.

${ }^{34}$ Didik Suhardi, "Peran SMP Berbasis Pesantren Sebagai Upaya Penanaman Pendidikan Karakter Kepada Generasi Bangsa," Jurnal Pendidikan Karakter 3 (2012): 316-328.

${ }^{35}$ Undang-Undang No. 20 Tahun 2003 tentang Sistem Pendidikan Nasional

${ }^{36}$ Sayyid Quthb, Fi Zhilal al Qur'an, Beirut: Dar al-Syuruq, 1975, h. 19

${ }^{37}$ www.wikipedia.org, "Multicultural Education" (2016): 1-10.

${ }^{38}$ Paul C. Gorski, "A Working Definition of Multicultural Education" (http://www.edchange.org, 2015).
} 
ISSN : 2656-3134 (Online) - 2338-3801 (Print)

Multicultural education is a progressive approach for transforming education that critiques and corrects color-blind and discriminatory curriculum, practices, and policies in education ${ }^{39}$.

Dari beberapa pendapat di muka dapat disimpulkan bahwa Pendidikan multikultural adalah seperangkat strategi dan bahan yang dikembangkan untuk membantu para guru dalam pendidikan dengan pendekatan progresif untuk mengubah pendidikan secara menyeluruh sekaligus merespon praktek kebijakan dan kurikulum yang diskriminasi dalam pendidikan.

Definisi ini didefinisikan untuk memperjelas definisi yang berbeda-beda dari beberapa ahli, karena para ahli berbeda pendapat tidak hanya tentang definisinya bahkan mereka berbeda dalam pendekatan maupun pernyataan tujuan. Namun para ahli punya kesamaan tujuan, seperti yang dikemukakan Banks bahwa tujuan pendidikan multikultural adalah untuk mereformasi sekolah dan institusi-institusi pendidikan yang lain, sehingga para pelajar dari ras, etnik dan kelompok-kelompok kelas sosial akan mengalami pendidikan yang sama ${ }^{40}$.

Sedangkan tujuan pendidikan multikultural dapat dikaitkan dengan tiga aspek, pertama aspek sikap (attitudinal goals) adalah untuk mengembangkan kesadaran dan kepekaan kultural, toleransi kultural, penghargaan terhadap identitas kultural, sikap responsive terhadap budaya, keterampilan untuk menghindari dan meresolusi konflik. Kedua, aspek pengetahuan (cognitive goals) adalah untuk memperoleh pengetahuan tentang bahasa dan budaya orang lain, dan kemampuan untuk menganalisis dan tentang kesadaran perspektif kultural. Ketiga, aspek pembelajaran (instructional goals) adalah untuk memperbaiki distorsi, stereotipe, dan kesalahpahaman tentang kelompok etnik dalam buku teks dan media pembelajaran; memberikan berbagai strategi untuk mengarahkan perbedaan di depan orang, memberikan alat-alat konseptual untuk komunikasi antar budaya;

\footnotetext{
${ }^{39}$ Donna Y Ford, "Why Education Must Be Multicultural: Addressing a Few Misperceptions With Counterarguments ," Gifted Child Today 37 , no. 1 (2014): 59-62, http://gct.sagepub.com/cgi/content/abstract/37/1/59.

40 James a Banks, "Multicultural Education: Historical Development, Dimensions, and Practice," JSTOR (1993): 3-14.
} 
mengembangkan keterampilan interpersonal; memberikan teknik-teknik evaluasi; membantu klarifikasi nilai; dan menjelaskan dinamika kultural ${ }^{41}$.

\section{Pengembangan Pendidikan Multikultural}

Kamus besar bahasa indonesia mendefinisikan pengembangan adalah hal mengembangkan; pembangunan secara bertahap dan teratur, dan yang menjurus ke sasaran yang dikehendaki. pengembangan berasal dari kata kembang, berkembang yang berarti mekar terbuka atau membentang (tentang barang yang berlipat atau kuncup): contoh parasutny a tidak mengembang; 2. menjadi bertambah sempurna (tentang pribadi, pikiran, pengetahuan, dan sebagainya): dengan kemampuan kosa kata yang terbatas, pikiran seseorang tidak dapat berkembang ${ }^{42}$. Sedangkan pengembangan pendidikan multikultural adalah pembangunan pendidikan multikultural secara bertahap, teratur, dan menjurus ke sasaran yang dikehendaki agar menjadi lebih sempurna.

Sasarannya adalah seperti yang dikemukakan oleh Banks sebelumya, juga memberikan para pelajar baik laki-laki maupun perempuan mempunyai kesempatan yang sama untuk mengalami keberhasilan dalam pendidikan.

Nilai-nilai multikulturalisme seperti toleransi, demokratis, dan keadilan ${ }^{43}$ perlu diinternalisasikan dalam jalur pendidikan. Karena akan berguna bagi peserta didik ketika mereka berhadapan dengan realitas kehidupan baik di dalam suatu kelas maupun di masyarakat yang beragam. Peserta didik dengan demikian harus belajar menerapkan visi multikulturalisme untuk berinteraksi dengan teman-teman kelas mereka. Oleh karenanya, pendidikan multikultural tidak hanya harus mampu menumbuhkan kesadaran, pengakuan dan penghargaan terhadap keragaman dan kemajemukan yang ada, namun juga mampu menginternalisasikannya dalam pribadi para peserta didik, sehingga melahirkan sikap empati, tindakan yang simpatik, yang berujung pada pembelaan terhadap kelompok yang mengalami

${ }^{41}$ Nurul Zuriah, "Model Pengembangan Pendidikan Kewarganegaraan Multikultural Berbasis Kearifan Lokal Dalam Fenomena Sosial Pasca Reformasi Di Perguruan Tinggi," Jurnal Penelitian Pendidikan 12 (2011): 63-72.

${ }^{42}$ Tim Penyusun Kamus Bahasa Indonesia, Kamus Besar Bahasa Indonesia. h 679

${ }^{43}$ Abdul Munir Mulkhan, Kesalehan Multikultural (Jakarta: Pusat Studi Agama dan Peradaban (PSAP) Muhammadiyah, 2005). 
ketidakberuntungan, penindasan, dan marjinalisasi yang didasarkan pada perbedaan $^{44}$

Model pendidikan berwawasan multikulturalisme perlu memperhatikan enam hal, yaitu : a. Pendidikan multikultural haruslah berdimensi —right to culture" dan identitas lokal; b. Kebudayaan Indonesia yang menjadi, artinya kebudayaan Indonesia merupakan Weltanshaunng yang terus berproses dan merupakan bagian integral dari proses kebudayaan mikro; c. Pendidikan multikultural normatif yaitu model pendidikan yang memperkuat identitas nasional yang terus menjadi tanpa harus menghilangkan identitas budaya lokal yang ada; d. Pendidikan multikultural merupakan suatu rekonstruksi sosial, artinya pendidikan multikultural tidak boleh terjebak pada xenophobia, fanatisme dan fundamentalisme, baik etnik, suku, ataupun agama; e. Pendidikan multikultural merupakan pedagogic pemberdayaan (pedagogy of empowerment) dan pedagogik kesetaraan dalam kebudayaan yang beragam (pedagogy of equity); f. Pendidikan multikultural bertujuan mewujudkan visi Indonesia masa depan serta etika bangsa ${ }^{45}$.

\subsection{Pola Interaksi Rasululloh Terhadap Non Muslim}

Rasululloh selalu berdialog dengan para Sahabat untuk bersikap adil terhadap siapapun, baik terhadap keluarga, sahabat, masyarakat muslim bahkan kepada non muslim. Sifat adil terhadap golongan non muslim termaktub dalam al Qur'an surat al Mumtahanah ayat 8 yang Artinya:

"Allah tidak melarang kamu untuk berbuat baik dan berlaku adil terhadap orang-orang yang tiada memerangimu Karena agama dan tidak (pula) mengusir kamu dari negerimu. Sesungguhnya Allah menyukai orang-orang yang berlaku adil" (60: 8).

Asbabun Nuzul ayat tersebut tentang Qatilah (seorang kafir) datang kepada Asma' binti Abi Bakr (anak kandungnya) untuk berbuat baik kepadanya. Konteks ini menegaskan bahwa Allah tidak melarang berbuat baik kepada orang yang tidak memusuhi agama Allah. Peristiwa ini diperjelas dengan riwayat lain bahwa bahwa

\footnotetext{
44 Tasnim Muhammad, "Implementasi Nilai-Nilai Multikultural Dalam Pendidikan Di Program Studi Pendidikan Bahasa Arab (PBA) Fakultas Tarbiyah Dan Bahasa IAIN Surakarta.”

45 Ibid. h. 4
} 
Siti Qatilah, istri Abu Bakr yang telah diceraikan pada zaman jahiliyyah, datang kepada anaknya, Asma' binti Abi Bakr, membawa bingkisan. Asma' menolak pemberian itu, bahkan ia tidak memperkenankan ibunya masuk ke dalam rumahnya. Setelah itu, ia mengutus seseorang kepada 'Aisyah (saudaranya) agar menanyakan hal itu kepada Rasulullah saw. Maka Rasulullah saw memerintahkan untuk menerimanya beserta pula bingkisannya dengan baik. Ayat ini menegaskan bahwa Allah tidak melarang berbuat baik kepada orang kafir yang tidak memusuhi agama Allah" ${ }^{46}$ Sikap tersebut akibat dari ayat-ayat yang mendorong untuk memusuhi orang-orang kafir, yang mempengaruhi cara berpikir kaum mukmin. sehingga mereka merasa berdosa ketika menyambung tali silaturrahim kepada kerabat mereka yang masih musyrik. Mereka mengira bahwa hal itu termasuk yang dilarang Allah, maka Allah SWT memberitahukan bahwa berbuat baik dan bersikap adil terhadap orang-orang kafir dzimmi tidak termasuk ke dalam hal yang dilarang Allah SWT'T7.

Surat al Mumtahanah ini berkaitan dengan pendidikan iman, penataan sosial kemasyarakatan, dan sistem negara dalam masyarakat berbudaya dan modern. Pendidikan iman yang membebaskan dari fanatisme bangsa, fanatisme jenis, fanatisme tanah air, fanatisme kerabat atau keluarga dengan meletakkan iman kepada Alloh di atas segalanya yakni Iman yang mengikis segala perbedaan jenis, bahasa, dan garis keturunan ${ }^{48}$. Hubungan sesama manusia harus senantiasa dijaga. Maka ketika di hadapan Rasulullah melintas jenazah orang Yahudi, beliau berdiri memberi penghormatan dengan alasan, "bukankah ia juga manusia" (alaysat nafsan) HR. Bukhori.

Rasulullah senantiasa berdialog untuk selalu menjaga Kebenaran dan Keadilan dengan sesama muslim bahkan dengan non musllim seperti dalam Kasus Zubair bin Awwam tentang persengketaan hak pengairan, Khalid bin Walid tentang tindakan pembunuhan, penganiayaan, dan kedzaliman yang dilakukannya bersama pasukannya terhadap penduduk Bani Jadzimah, dan kasus Sawad bin

\footnotetext{
${ }^{46}$ KHQ Shaleh dkk, "Asbabun Nuzul Surat Al Mumtahanah,” Http://www.tafsironline.org.

${ }^{47}$ Musa, Tafsir Al Qur'an Hidayatul Insan Jilid IV. h.271

${ }^{48}$ Sayyid Quthub, "Terjemah Tafsir Fi Zhilalil Qur'an XI," in Juz XXVIII: Al-Mujadalah S.d. atTahrim, n.d., 238.
} 
Ghaziyyah tentang kesalahan kecil19. Dialog Nabi dengan para Sahabat terdapat dalam Surat an Nisa' ayat 105, Ayat ini dan beberapa ayat berikutnya merupakan gambaran dialog Nabi dengan para Sahabat tentang keadilan. Ketika itu Thu'mah menyembunyikan barang curian di rumah seorang Yahudi. Thu'mah tidak mengakui perbuatannya itu malah menuduh bahwa yang mencuri barang itu orang Yahudi. Hal ini diajukan oleh kerabat-kerabat Thu'mah kepada Nabi Saw dan mereka meminta agar Nabi membela Thu'mah dan menghukum orang-orang Yahudi, kendatipun mereka tahu bahwa yang mencuri barang itu ialah Thu'mah, Nabi sendiri hampir-hampir membenarkan tuduhan Thu'mah dan kerabatnya itu terhadap orang Yahudi ${ }^{50}$.

Al-Qur'an Surat an Nur ayat 22. Ayat ini merupakan dialog Nabi dengan para Sahabat yang berhubungan dengan sumpah Abu Bakar r.a. bahwa dia tidak akan memberi apa-apa pada kerabatnya ataupun orang lain yang terlibat dalam menyiarkan berita bohong tentang Aisyah. Maka turunlah ayat ini melarang beliau melaksanakan sumpahnya itu dan menyuruh mema'afkan dan berlapang dada terhadap mereka sesudah mendapat hukuman atas perbuatan mereka itu ${ }^{51}$. Kemudian, Surat al fath ayat 10 tentang peristiwa yang terjadi pada bulan zulkaidah tahun keenam hijriyah, Nabi Muhammad saw berserta para pengikutpengikutnya hendak mengunjungi Mekkah untuk melakukan umrah dan melihat keluarga-keluarga mereka yang telah lama ditinggalkan. Sesampai di Hudaibiyah beliau berhenti dan mengutus Utsman bin Affan lebih dahulu ke Mekkah untuk menyampaikan maksud kedatangan beliau dan kaum muslimin ${ }^{52}$.

Karena sifat-sifat Rasulullah yang toleran terhadap masyarakat non muslim, banyak dari kalangan Yahudi dan Nasrani yang masuk Islam. Diantaranya tertuang dalam Surat ar Ra'du Ayat 36 Yaitu tentang orang-orang Yahudi yang telah masuk agama Islam seperti Abdullah bin Salam dan orang-orang Nasara yang telah memeluk agama Islam ${ }^{53}$. Ayat-Ayat tentang dialog Nabi dengan Para Sahabat untuk menegakkan keadilan yang lain terdapat dalam Surat an Nisa' Ayat 135

\footnotetext{
${ }^{49}$ Ikhwan, "Pengadilan HAM: Penyelesaian Kasus Pelanggaran HAM Di Masa Rasulullah SAW," Harmoni 8 (2009). h. 80

${ }^{50}$ Naf'an Akhun, $A L$ QUR'AN Digital 2.1.

${ }^{51}$ Ibid. h. 545

${ }^{52}$ Ibid. h. 834

${ }^{53}$ Ibid. h. 373
} 
tentang keharusan berbuat adil h. 146, Surat an-Nisa' Ayat 58 h 130, kewibawaan berlaku adil Surat al Maidah ayat 8 h 161, al Maidah ayat 42 h 168, al Maidah ayat 95 h 179, al An'am ayat 152 h. 216, al A'raf ayat 29 h 225, mencari keadilan dengan berpedoman petunjuk dan tuntunan Alloh Surat al A'raf ayat 159 h 247, al A'raf ayat 181 h 252, Surat Yunus ayat 4 h 303, Surat an Nahl ayat 90 h $413^{54}$.

\subsection{Definisi Dialog}

Sebelum membahas dialog, penulis ingin menjelaskan kata musyawarah, kata musyawarah diambil dari akar kata sy-, w-, r-, yang pada mulanya bermakna mengeluarkan madu dari sarang lebah. Makna ini kemudian berkembang, sehingga mencakup segala sesuatu yang dapat diambil atau dikeluarkan dari yang lain (termasuk pendapat). Musyawarah dapat juga berarti mengatakan atau mengajukan sesuatu. Kata musyawarah pada dasarnya hanya digunakan untuk halhal yang baik, sejalan dengan makna dasarnya ${ }^{55}$. Dalam al-Qur'an terdapat tiga ayat Al-Quran yang akar katanya menunjukkan musyawarah, diantaranya:

a. Dalam Al-Quran surat Al-Baqarah (2): 233

Apabila keduanya (suami istri) ingin menyapih anak mereka (sebelum dua tahun) atas dasar kerelaan dan permusyawarahan antar mereka, maka tidak ada dosa atas keduanya. Ayat ini membicarakan bagaimana seharusnya hubungan suami istri saat mengambil keputusan yang berkaitan dengan rumah tangga dan anak-anak, seperti menyapih anak. Pada ayat di atas, Al-Quran memberi petunjuk agar persoalan itu (dan juga persoalan-persoalan rumah tangga lainnya) dimusyawaraLkan antara suami-istri.

b. Dalam surat Ali 'Imran (3): 159

Maka disebabkan rahmat dari Allahlah, engkau bersikap lemah lembut terhadap mereka. Seandainya engkau bersikap kasar dan berhati keras, niscaya mereka akan menjauhkan diri dari sekelilingmu. Karena itu, maafkanlah mereka, mohonkanlah ampun bagi mereka, dan bermusyawarahlah dengan mereka dalam urusan (tertentu). Kemudian apabila engkau telah membulatkan

\footnotetext{
54 Ibid.

${ }^{55}$ M Quraish Shihab, Wawasan Al Qur'an Tafsir Maudhu'i Atas Pelbagai Persoalan Umat (Jakarta: Mizan, 1996).
} 
ISSN : 2656-3134 (Online) - 2338-3801 (Print)

tekad, bertawakallah kepada Allah. Sesungguhnya Allah menyukai orang-orang yang bertawakal kepada-Nya.

Ayat ini dari segi redaksional ditujukan kepada Nabi Muhammad Saw. agar memusyawarahkan persoalan-persoalan tertentu dengan sahabat atau anggota masyarakatnya. Ayat ini juga merupakan petunjuk kepada setiap Muslim, khususnya kepada setiap pemimpin, agar bermusyawarah dengan anggotaanggotanya ${ }^{56}$.

c. Dalam surat Al-Syura (42): 38,

Allah menyatakan bahwa orang mukmin akan mendapat ganjaran yang lebih baik dan kekal di sisi Allah. Adapun yang dimaksud dengan orang-orang mukmin itu adalah: Orang-orang yang mematuhi seruan Tuhan mereka, melaksanakan shalat (dengan sempurna), serta urusan mereka diputuskan dengan musyawarah antar mereka, dan mereka menafkahkan sebagian rezeki yang Kami anugerahkan kepada mereka.

Ayat ketiga ini turun sebagai pujian kepada kelompok Muslim Madinah (Anshar) yang bersedia membela Nabi Saw. Dan menyepakati hal tersebut melalui musyawarah yang mereka laksanakan di rumah Abu Ayyub Al-Anshari. Namun demikian, ayat ini juga berlaku umum, mencakup setiap kelompok yang melakukan musyawarah ${ }^{57}$.

QS Ali 'Imran [3]: 128, Ayat ini turun berkaitan dengan ucapan Nabi Saw. ketika beliau dilukai oleh kaum musyrikin pada perang Uhud. "Bagaimana Allah akan mengampuni mereka, sedangkan mereka telah mengotori wajah Nabi Saw. dengan darah"? Dari riwayat lain dikemukakan, bahwa ayat ini turun untuk menegur Nabi Saw. yang mengharapkan agar Tuhan menyiksa orang-orang tertentu dan memaafkan orang-orang 1ain.

Ketika Nabi Saw. memilih suatu lokasi untuk pasukan Islam menjelang berkecamuknya perang Badar, sahabat Al-Khubbab bin Al-Munzir yang memiliki pandangan berbeda tidak mengajukan usulnya kecuali setelah bertanya. Dan setelah

56 Ibid.

${ }^{57}$ Ibid. 
Mendengar jawaban "Tempat ini adalah pilihan berdasar nalar, strategi perang, dan tipu muslihat,". Barulah Al-Khubbab mengajukan usul untuk memilih lokasi lain di dekat sumber air, kemudian disetujui oleh Nabi Saw. Demikian diriwayatkan oleh Al-Hakim. Ketika terjadi perundingan Hudaibiyah, sebagian besar sahabat Nabi Saw. terutama Umar bin Khaththab, amat berat hati menerima rinciannya, namun semuanya terdiam ketika Nabi bersabda. "Aku adalah Rasulullah Saw." 58.

Nabi tidak hanya bermusyawarah dalam hal-hal yang berkaitan dengan urusan masyarakat dan negara, beliau pun bermusyawarah dalam beberapa persoalan pribadi. Salah satu kasus keluarga yang beliau musyawarahkan adalah kasus fitnah terhadap istri beliau Aisyah r.a. yang digosipkan telah menodai kehormatan rumah tangga. Ketika gosip menyebar, Rasulullah Saw. bertanya kepada beberapa orang sahabat maupun keluarganya ${ }^{59}$. Walhasil, bisa disimpulkan bahwa musyawarah dapat dilakukan untuk segala masalah, tetapi Hal-hal yang berkaitan dengan kehidupan akhirat atau persoalan ibadah, tidak dapat dimusyawarahkan.

Ayat-ayat musyawarah yang dikutip di atas tidak menetapkan sifat-sifat mereka yang diajak bermusyawarah, tidak juga jumlahnya. Namun demikian, dari As-Sunnah dan pandangan ulama, sifat-sifat umum yang hendaknya dimiliki yang diajak bermusyawarah. Satu dari sekian riwayat menyatakan bahwa Rasul Saw. pernah berpesan kepada Imam Ali bin Abi Thalib sebagai berikut:

Wahai Ali, jangan bermusyawarah dengan penakut, karena dia mempersempit jalan keluar. Jangan juga dengan yang kikir, karena dia menghambat engkau dari tujuanmu. Juga tidak dengan yang berambisi, karena dia akan memperindah untukmu keburukan sesuatu. Ketahuilah wahai Ali, bahwa takut, kikir, dan ambisi, merupakan bawaan yang sama, kesemuanya bermuara pada prasangka buruk terhadap Allah.

Imam Ja'far Ash-Shadiq pun berpesan,

Bermusyawarahlah dalam persoalan-persoalanmu dengan seseorang yang memiliki lima hal: akal, lapang dada, pengalaman, perhatian, dan takwa.

Dalam konteks memusyawarahkan persoalan-persoalan masyarakat, praktek yang dilakukan Nabi Saw. cukup beragam. Terkadang beliau memilih

${ }^{58}$ Ibid.

${ }^{59}$ Ibid. 
ISSN : 2656-3134 (Online) - 2338-3801 (Print)

orang tertentu yang dianggap cakap untuk bidang yang dimusyawarahkan, terkadang juga melibatkan pemuka-pemuka masyarakat, bahkan menanyakan kepada semua yang terlibat di dalam masalah yang dihadapi. Sebagian pakar tafsir membicarakan musyawarah dan orang-orang yang terlibat di dalamnya ketika mereka menafsirkan firman Allah dalam Al-Quran surat Al-Nisa'(4): 59: Wahai orang-orang yang beriman, taatilah Allah dan taatilah Rasul-(Nya), dan ulil amr di antara kamu. Kemudian jika kamu berbeda pendapat mengenai suatu hal, kembalikanlah kepada (jiwa ajaran) Allah (Al-Quran) dan (jiwa ajaran) Rasul (sunnahnya). Yang demikian itu lebih utama (bagimu) dan lebih baik akibatnya (QS Al-Nisa [4]: 59).

Dalam ayat itu terdapat kalimat u1u1 amr, yang diperintahkan untuk ditaati. Kata amr di sini berkaitan dengan kata amr yang disebutkan dalam Al-Quran surat Al-Syura ayat 38 (persoalan atau urusan mereka, merekalah yang memusyawarahkan). Tentunya tidak mudah melibatkan seluruh anggota masyarakat dalam musyawarah itu, tetapi keterlibatan mereka dapat diwujudkan melalui orang-orang tertentu yang mewakili mereka, yang oleh para pakar diberi nama berbeda-beda sekali Ahl Al-Hal wa Al-'Aqd, dikali lain Ahl Al-Ijtihad, dan kali ketiga Ahl Al-Syura.

Dapat disimpulkan bahwa Ahl Al-Syura merupakan istilah umum, yang kepada mereka para penguasa dapat meminta pertimbangan dan saran. Jika demikian, tidak perlu ditetapkan secara rinci dan ketat sifat-sifat mereka, tergantung pada persoalan apa yang sedang dimusyawarahkan. Sebagian pakar kontemporer memahami istilah Ahl Al-Hal wa Al-'Aqd sebagai orang-orang yang mempunyai pengaruh di tengah masyarakat, sehingga kecenderungan mereka kepada satu pendapat atau keputusan mereka dapat mengantarkan masyarakat pada hal yang sama

Muhammad Abduh memahami Ahl Al-Hal wa Al-'Aqd sebagai orang yang menjadi rujukan masyarakat untuk kebutuhan dan kepentingan umum, yang mencakup pemimpin formal maupun non-formal, sipil maupun militer. Adapun Ahl Al-Ijtihad adalah kelompok ahli dan para teknokrat dalam berbagai bidang dan disiplin ilmu ${ }^{60}$.

${ }^{60}$ Ibid. 


\subsection{Dialog Antar Umat Beragama}

Berbagai macam persoalan yang disebabkan oleh perbedaan niscaya dapat diselesaikan dengan jalan dialog. Ada tiga hal yang dipandang penting khususnya bagi umat Islam sebagai modal awal dalam menjalin interaksi antar maupun intern umat beragama; yakni: 1). Selalu berpegang teguh pada aqidah yang lurus yakni tauhidullah (tauhid kepada Allah) dan menafikan selain-Nya., 2. Berakhlak mulia, dan 3. Berilmu, karena Ilmu adalah asas seluruh hal yang mulia dan akhir dari kedudukan yang tinggi ${ }^{61}$. Karena itulah, konsep dialog harus menyentuh hati nurani dan umat secara keseluruhan, bukan hanya retorika yang siap ditinggalkan karena hanya berhenti di lidah dan bangku seminar ${ }^{62}$.

Kerukunan umat beragama yakni keadaan hubungan sesama umat beragama yang dilandasi oleh toleransi, saling pengertian, saling menghormati, menghargai kesetaraan dalam pengamalan ajaran agamanya dan kerjasama dalam kehidupan bermasyarakat, berbangsa dan bernegara di dalam kerangka NKRI berdasarkan Pancasila dan UUD 194563. Disamping landasan tersebut, Masing-masing agama juga mempunyai ajaran-ajaran yang menghargai perbedaan. Setidaknya ia menghormati keberadaan agama lain. Seperti dalam Islam, Al-Quran mengajarkan: "Bagimu agamamu dan bagiku agamaku”. (QS. Al-Kafirun: 6). Ayat ini menegaskan tentang toleransi, yang mengajarkan bahwa beragama itu bukan karena paksaan melainkan karena tuntutan hati atau hidayah. Dalam berdakwah pun, al-Quran telah menjelaskan: "Ajaklah mereka kepada jalan Tuhanmu dengan (cara) bikmah dan nasehat yang baik" "64. Berkaitan dengan dakwah, disebutkan dalam surat Yusuf ayat 108 yang artinya:

Artinya: "Katakanlah (Mubamad), Inilab jalanku, aku dan orang-orang yang mengikutiku mengajak (kamu) kepada Allah dengan bujjah yang nyata, Mahasuci Allah, dan aku tidak termasuk orang-orang musyrik" (12:108).

${ }^{61}$ Achmad Rosyidi, "Penguatan Integritas Bangsa Melalui Internalisasi Ajaran Agama," Harmoni 8 (2009): 29. h. 29

${ }^{62}$ Ibid. h. 29

${ }^{63}$ Pasal 1 Bab I Peraturan Bersama Menteri Agama dan Menteri Dalam Negeri No 9 dan 8 Tahun 2006, Badan Litbang Dep. Agama RI, 2006, hal 36.

${ }^{64}$ Endang Turmudzi, "Masalah Kerukunan Umat Beragama." h. 516 
Ibnu Katsir berpendapat bahwa Allah berfirman kepada RasulNya yang diutus kepada manusia dan jin, memerintahkan kepadanya agar memberitahu kepada manusia bahwa inilah jalannya, maksudnya adalah cara, jalan dan sunnahNya, yaitu dakwah kepada syahadah bahwa tidak ada Tuhan yang haq selain Alloh yang Maha esa dan tidak ada sekutu bagiNya, dengan jalan itu dia mengajak kepada Allah berdasarkan bukti, dalil, dan keyakinan ${ }^{65}$. Tafsir Hidayatul Insan menjelaskan bahwa ajakan kepadaNya merupakan jalan yang menghubungkan kepada Allah dan surga-Nya. Jalan yang di dalamnya mengandung ilmu pengetahuan terhadap kebenaran. Yakni ilmu untuk diamalkan, diutamakan, serta diikhlaskan karena Allah dalam menjalankan agama. Di atas ilmu dan keyakinan tanpa keraguan tanpa menisbatkan dan menafikan kesempurnaan kepada-Nya. Bahkan Nabi Muhammad SAW menjalankan agama ikhlas karena Allah Ta'ala ${ }^{66}$.

Universalitas dakwah Islam menuntut cara-cara yang santun dan elegan agar tercipta stabilitas dan kedamaian untuk semua umat manusia. Bahkan, al-Qur'an Surat Mumtahanah ayat 8 membolehkan umat Islam untuk hidup berdampingan secara damai dengan siapa saja selama mereka tidak memerangi karena agama, dan atau mengusir kaum muslimin dari rumah-rumah mereka. Kemudian al-Qur'an Surat Al-Maaidah ayat 8 tetap memerintahkan umat Islam untuk berbuat adil kepada suatu kelompok dan memenuhi hak-hak mereka meskipun umat Islam tidak suka dengan kelompok tersebut ${ }^{67}$. Dan Al-Qur'an Surat Yunus Ayat 99 menunjukkan pengakuan terhadap keragaman agama dan keyakinan yang ada dalam masyarakat. Sudah menjadi sunnatullah -berdasar ayat ini- bahwa tidak mungkin akan terjadi semua manusia beriman (masuk menjadi pemeluk Islam). Jika ada yang memaksakan kehendak agar semua orang mengikuti ajaran agama tertentu, maka berarti ia tidak memahami akan keragaman agama dan keyakinan yang sudah menjadi ketentuan Allah. Bahkan seorang nabi pun -sebagaimana ayat tersebut menyatakan- tidak memiliki hak untuk memaksa orang mengikutinya ${ }^{68}$.

\footnotetext{
${ }^{65}$ Abdullah Bin Muhammad Bin Abdurrahman Bin Ishaq al Syeikh, "Terjemah Tafsir Ibnu Katsir," in 4, ed. M. Yusuf Harun MA Dkk, I. (Bogor: Pustaka Imam asy Syafi'i, 2003), 466. Juz 13 ${ }^{66}$ Abu Yahya Marwan Bin Musa, Tafsir Al Qur'an Hidayatul Insan Jilid I (www.tafsir.web.id, n.d.). h. 260

${ }^{67}$ Fauziyah, "Potret Kerukunan Hidup Umat Beragama Di Kabupaten Bondowoso Jawa Timur." h. 648

${ }^{68}$ Ibid. h. 648
} 
Pada puncaknya, Nabi Muhammad memberikan contoh ketika beliau membuat "Perjanjian Madinah" yang disepakati bersama kalangan non-Islam. Perjanjian tersebut bertumpu pada kesepakatan untuk hidup berdampingan dengan melakukan kewajiban masing-masing dan saling menghormati ${ }^{69}$. Untuk itu toleransi antar umat beragama merupakan hal yang penting untuk selalu dibina dan ditingkatkan. Karena dengan saling bertoleransi antar sesama, akan tercipta kedamaian dan keharmonisan. Ummat Islam sejak dulu hingga kini telah terbiasa hidup di tengah kebhinnekaan atau pluralitas agama dan menerimanya sebagai realitas sosial ${ }^{70}$.

Sedangkan Dialog agama (baik dalam konteks dialog antar agama atau dialog intern agama) terjadi bila setiap individu dan kelompok yang berbeda agama atau mazhab pemikiran bertemu dalam sebuah ruang atau forum untuk melakukan pembicaraan $^{71}$. Dialog bertujuan untuk meningkatkan saling memahami, bukan merasa sukses dengan argumen untuk dapat mengalahkan yang lain. Semangat yang dicari dalam dialog adalah common values and strengths yang bisa dijadikan sebagai pedoman bersama atau solusi bersama untuk membangun hubungan keagamaan yang sehat dan saling memahami dalam perbedaan, bukan mencari kelemahan tiap-tiap kelompok yang kemudian dipakai untuk menyerang balik lawan. Dalam dialog, bertanya adalah untuk meningkatkan pemahaman bukan menjatuhkan lawan seperti umumnya dalam debat. Perbedaan-perbedaan tidak dibiarkan begitu saja yang kemudian menjadi sumber konflik, kekerasan, dan pertikaian $^{72}$. Karena esensi utama dialog sesungguhnya adalah melakukan transformasi konflik kekerasan ke budaya komunikasi ${ }^{73}$.

Pemahaman manusia terhadap efektifitas komunikasi juga penting, karena pada dasarnya konflik dapat juga disebabkan masalah-masalah komunikasi ${ }^{74}$. Bahkan, kebuntuan jalan keluar dari konflik-konflik tersebut boleh jadi karena cara

\footnotetext{
${ }^{69}$ Endang Turmudzi, "Masalah Kerukunan Umat Beragama." h. 516

${ }^{70}$ Fauziyah, "Potret Kerukunan Hidup Umat Beragama Di Kabupaten Bondowoso Jawa Timur." h. 648

${ }^{71}$ Achmad Rosyidi, "Penguatan Integritas Bangsa Melalui Internalisasi Ajaran Agama." h. 29

${ }^{72}$ Ibid., h. 29

${ }^{73}$ Subhi Azhar, "Rethinking Dialogue: Antara Konflik Dan Perubahan Damai," Harmoni 10 (2011). h. 541

${ }^{74}$ Ibid. h. 541
} 
ISSN : 2656-3134 (Online) - 2338-3801 (Print)

pandang yang kaku terhadap identitas atau keengganan memperbaiki komunikasi yang buruk 75 .

Setiap persoalan ada solusinya, Agama telah mengajarkan agar setiap orang berkomunikasi, mengklarifikasi sesuatu yang tidak jelas, menanyakan sesuatu yang tidak diketahui, dan sebagainya dalam setiap agama diajarkan untuk melakukannya ${ }^{76}$. Sebagaimana diajarkan oleh Al-Qur'an, dialog ketika menghadapi orang-orang yang berbeda keyakinan itu dikembangkan dengan semangat bikmah dan manizhah hasanah seperti disinggung di muka ${ }^{77}$. Al-qur'an juga menjadi landasan dan tuntunan komunikasi Islami, sementara Nabi Muhammad SAW yang menjadi modelnya. Kita dapat meneladani keduanya dalam berkomunikasi dalam pelbagai konteks sosial ${ }^{78}$. Lanjutnya, ada enam komunikasi Islam dalam al Qur'an, pertama qaulan ma'rufan [QS an-Nisa'[4]:8], kedua qaulan sadiidan [QS anNisa'[4]:9], ketiga, qaulan balighan [QS an-Nisa'[4]:63], keempat, qaulan kariman [QS al-isra'[17]:23], kelima qaulan maysuuran [al-isra'[17]:28], keenam qaulan layyinan [Thaha [20]:44].

Pertama, qaulan ma'rufan [QS an-Nisa'[4]:8] yang artinya:

Artinya: Dan apabila sewaktu pembagian (warisan) itu hadir beberapa kerabat, anakanak yatim dan orang-orang miskin, maka berilah mereka dari harta itu (sekedarnya) dan ucapkanlah kepada mereka perkataan yang baik.

qaulan ma'rufan di sini ditafsiri Yakni jika ternyata tidak mungkin karena halhal tertentu, maka berbicaralah pada mereka dengan kata-kata yang lembut ${ }^{79}$.

Kedua, qaulan sadiidan [QS an-Nisa'[4]:9] yang artinya:

Artinya: Dan hendaklah takut (kepada Allah) orang-orang yang sekiranya mereka meninggalkan keturunan yang lemah di belakang mereka yang mereka khawatir terhadap (kesejabteraan)nya. Oleh sebab itu, hendaklah mereka bertakwa kepada Allah, dan hendaklah mereka berbicara dengan tutur kata yang benar.

Ketiga, qaulan balighan terdapat dalam [QS an-Nisa'[4]:63] yang berbunyi:

\footnotetext{
${ }^{75}$ Ibid. h. 534

${ }^{76}$ Ibid. h. 541

${ }^{77}$ Achmad Rosyidi, "Penguatan Integritas Bangsa Melalui Internalisasi Ajaran Agama.” h. 29

${ }^{78}$ Hasan Basri Tanjung, "Bertutur Kata," Khazanah Republika, April 2015.

${ }^{79}$ Musa, Tafsir Al Qur'an Hidayatul Insan Jilid I. h. 231
} 
ISSN : 2656-3134 (Online) - 2338-3801 (Print)

Artinya: Mereka itu adalah orang-orang yang Allah mengetahui apa yang ada di dalam hatinya. Karena itu berpalinglab kamu dari mereka, dan berilah mereka nasehat, dan katakanlah kepada mereka perkataan yang membekas pada jiwanya.

qaulan balighan di sini ditafsiri, Misalnya secara sir (rahasia), karena yang demikian dapat membuahkan hasil. Dalam ayat ini terdapat dalil, bahwa pelaku maksiat, jika berpaling, maka dinasehati secara rahasia dan menasehati dengan kata-kata yang bisa membekas di hatinya ${ }^{80}$.

Keempat qaulan kariman [QS al-isra'[17]:23] yang berbunyi:

Artinya: Dan Tubanmu telah memerintabkan agar kamu jangan menyembah selain Dia dan hendaklah berbuat baik kepada ibu-bapak. Jika salah seorang di antara keduanya atau keduaduanya sampai berusia lanjut dalam pemeliharaanmu, maka sekali-kali janganlah engkau mengatakan kepada keduanya perkataan "ah" dan janganlah engkau membentak. keduanya, dan ucapkanlah kepada keduanya perkataan yang baik.

Yakni perkataan yang dicintai keduanya serta menenteramkan hati keduanya, dan hal ini disesuaikan dengan keadaan, kebiasaan dan zaman ${ }^{81}$.

Kelima qaulan maysuuran [al-isra'[17]:28] yang berbunyi:

Artinya: Dan jikea engkau berpaling dari mereka untuk memperoleb rabmat dari Tubanmu yang engkau barapkan, maka katakanlah kepada mereka ucapan yang lemah lembut.

Maksudnya, apabila kamu tidak dapat melaksanakan perintah Allah seperti yang tersebut dalam ayat 26, maka katakanlah kepada mereka perkataan yang baik agar mereka tidak kecewa karena mereka belum mendapat bantuan dari kamu. Dalam keadaan seperti itu, kamu berusaha untuk mencari rezeki (rahmat) dari Tuhanmu, sehingga kamu dapat memberikan kepada mereka hak-hak mereka. Contoh ucapan yang lemah lembut adalah berjanji akan memberikan bantuan kepada mereka ketika ada rezeki. Hal ini termasuk ibadah, karena berniat untuk berbuat baik adalah sebuah kebaikan. Oleh karena itu, sepatutnya seorang hamba melakukan perbuatan baik yang bisa dilakukan dan memiliki niat baik untuk perkara yang belum bisa dilakukan, agar memperoleh pahala terhadapnya dan boleh jadi Allah memudahkannya karena harapan yang ada dalam dirinya ${ }^{82}$.

\footnotetext{
${ }^{80}$ Ibid. h. 272

${ }^{81}$ Musa, Tafsir Al Qur'an Hidayatul Insan Jilid II.h. 369

${ }^{82}$ Ibid. h. 371
} 
ISSN : 2656-3134 (Online) - 2338-3801 (Print)

Keenam qaulan layyinan [Thaha [20]:44] yang berbunyi:

Artinya: Maka berbicaralah kamu berdua kepadanya (Firaun) dengan kata-kata yang lemah lembut, mudah-mudahan dia sadar atau takut.

Yakni dengan lembut dan beradab, Ucapan yang lembut dapat membuat orang lain menerima, sedangkan ucapan yang keras dapat membuat orang lain menjauh. Contoh Nabi Musa 'alaihis salam yang mengikuti perintah Allah untuk menasehati Fir'aun, ketika sampai kepada Fir'aun, Musa berkata sesuai perintah Allah, "Adakah keinginanmu untuk membersibkan diri, dan engkau akan aku arabkan ke jalan Tuhanmu agar Engkau takut kepada-Nya?’ (lihat surah An Naazi'at: 18-19) sepeti inilah cara yang perlu dilakukan da'i, yakni perkataannya tidak menunjukkan paksaan, tetapi menunjukkan pilihan dan penawaran seperti dengan kata-kata, “Maukah? Mungkin? Barang kali?” dsb. Karena hal ini lebih bisa diterima daripada perkataan yang terkesan memaksa atau mengajari, terlebih kepada orang yang lebih tua. Perhatikanlah kalimat tersebut, "Adakah keinginanmu untuk membersibkan diri...dst." Kalimatnya tidak "Agar aku bersihkan dirimu?” tetapi “membersihkan diri?” yang menunjukkan biarlah ia membersihkan dirinya sendiri setelah mengingatkan sesuatu yang membuatnya berpikir. Kemudian Musa 'alaihis salam mengajaknya kepada jalan Tuhannya yang telah mengaruniakan berbagai nikmat yang nampak maupun yang tersembunyi, di mana nikmat-nikmat itu sepatutnya disyukuri dengan mengikuti perintah-perintah-Nya. Namun ternyata Fir'aun tidak menerima nasehat yang lembut itu, maka semakin jelaslah, bahwa peringatan tidak bermanfaat baginya, sehingga pantas jika Allah menghukumnya ${ }^{83}$.

Dari beberapa paparan tentang berkomunikasi tersebut, dapat disimpulkan bahwa Islam melalui al Qur'an mengajarkan komunikasi yang baik yakni dengan qaulan ma'rufan, berbicara dengan kata-kata yang lembut. Kedua qaulan sadiidan yaitu berbicara dengan tutur kata yang benar. Ketiga qaulan balighan, yaitu menasehati secara rahasia dan menasehati dengan kata-kata yang bisa membekas di hatinya. Keempat, qaulan kariman Yakni berkata yang menenteramkan hati yang disesuaikan dengan keadaan, kebiasaan dan zaman. Kelima qaulan maysuuran yaitu

${ }^{83}$ Ibid. h. 466 
perkataan yang baik agar tidak mengecewakan karena belum mendapat yang diharapkan. Keenam qaulan layyinan yaitu perkataan yang lembut dan beradab, tidak membual (mengada-ada), tidak keras ucapannya dan tidak kasar sikapnya.

Konsep dakwah, musyawarah, dan cara komunikasi yang diajarkan dalam Islam sebagaimana telah dibahas di atas, menjadi landasan bagi umat muslim untuk membina kerukunan intern dan antar umat beragama yang membutuhkan wadah. Wadah ini dijadikan ajang bagi para pemuka agama untuk saling mengenal dan bersosialisasi.

Kerukunan umat beragama secara formal digunakan pertama kali pada saat penyelenggaraan Musyawarah Antar Umat Beragama oleh pemerintah pada tanggal 30 Nopember 1967 di Gedung Dewan Pertimbangan Agung Jakarta. Musyawarah tersebut adalah pertemuan awal antara pemimpin berbagai agama di Indonesia untuk membahas persoalan-persoalan yang mendasar bagi keberlangsungan kehidupan keagamaan ${ }^{84}$. Pemerintah melalui Departemen Agama yang dipimpin oleh Mukti Ali, membagi kegiatan keagamaan ke dalam dua bentuk, yakni murni bersifat agama dan bersifat politis. Pertama, pemerintah membolehkan, bahkan medukung, segala bentuk kegiatan keagamaan masyarakat yang berkaitan dengan peningkatan penghayatan agama. Tetapi harus segera ditekankan bahwa pemerintah menghindari segala bentuk kegiatan keagamaan yang disandarkan, atau cenderung mengarah, kepada perjuangan politis ${ }^{85}$. Hal ini dilakukan untuk memperjelas posisi agama dan poltik agar tidak dicampur aduk.

Sedangkan berkenaan dengan kerukunan hidup umat beragama dibuat Surat Keputusan Bersama (SKB) Menteri Agama dan Menteri Dalam Negeri Nomor 1 Tahun 1969. Ketika Alamsyah Ratu Perwiranegara menjabat Menteri Agama, wadah kerukunan dibentuk dengan nama Wadah Musyawarah Antar Umat Beragama (WMAUB) berdasarkan Surat Keputusan Menteri Agama Nomor 35 tanggal 30 Juni 1980. Wadah tersebut memiliki fungsi sebagai forum konsultasi dan komunikasi antar para pemuka agama ${ }^{86 .}$

\footnotetext{
${ }^{84}$ Muhaimin (ed.), Damai Di Dunia Damai Untuk Semua; Perspektif Berbagai Agama, Bunga Rampai (Jakarta: Puslitbang Kehidupan Beragama Balitbang Dep. Agama, 2004).

${ }^{85}$ H. Haidlor Ali Ahmad, Revitalisasi Wadah Kerukunan Umat Beragama, ed. H. Haidlor Ali Ahmad, I. (Jakarta: CV. PRASASTI, 2009).

${ }^{86}$ Ibid.
} 
Sejarah berlanjut ketika Tarmidzi Taher menjabat Menteri Agama melalui Proyek Pembinaan Kerukunan Umat Beragama membentuk Lembaga Pengkajian Kerukunan Antar Umat Beragama (LPKUB) di Yogyakarta, Medan dan Ambon. Fungsi dan tujuan dibentuknya lembaga pengkajian ini tidak jauh berbeda dengan WMUB. Perbedaannya, LPKUB lebih menekankan pada pengkajian yang melibatkan cendekiawan-cendekiawan dari berbagai agama. Keduanya, baik LPKUB maupun WMAUB dibentuk dan dibiayai oleh pemerintah (top-down), dan lebih diperuntukan kalangan elit dan kurang menyentuh masyarakat bawah ${ }^{87}$. Departemen Agama juga mendirikan forumforum beranggotakan tokoh agama-agama yang berfungsi sebagai jembatan antar umat beragama dengan pemerintah atau Departemen Agama. Forum-forum itu adalah Majelis Ulama Indonesia (MUI), Persatuan Gereja Indonesa (PGI), Konferensi Wali Gereja Indonesia (KWI), Parisadha Hindu Darma Indonesia (PHDI), dan Perwalian Umat Budha Indonesia (WALUBI). Melalui forumforum itu diharapkan agama bertindak sebagai kekuatan pemersatu bagi para pemeluk agama masing-masing 88 .

Sejarah berubah setelah terjadi pergeseran kekuasaan, dengan runtuhnya rezim orde baru dan digantikan oleh orde reformasi, banyak terjadi konflik terbuka di berbagai daerah, seperti di Pontianak, Sampit, Ambon, Poso dan lain-lain. Setelah mereka jenuh dengan konflik, mereka mulai berupaya menghidupkan kembali (revitalisasi) kearifan lokal yang pernah mereka miliki untuk merekatkan tali persatuan. namun belakangan kurang berfungsi ${ }^{89}$. Disusul dengan usaha pemerintah untuk membina kerukunan umat beragama melalui penelitian untuk mengetahui sejauh mana masyarakat secara bottom up membangun wadah kerukunan sebelum adanya Peraturan Bersama Menteri Agama dan Menteri Dalam Negeri (PBM) Nomor 9 dan 8 Tahun 2006, antara lain memuat Pemberdayaan Forum Kerukunan Umat Beragama (FKUB) yang pembentukannya di tingkat kecamatan tidak diatur dalam PBM namun juga tidak dilarang ${ }^{90}$. Hasil dari penelitian tersebut menggambarkan bagaimana tokoh agama

\footnotetext{
87 Ibid.

88 Ibid.

${ }^{89}$ Ibid.

90 Ibid.
} 
dan masyarakat tingkat kecamatan membangun wadah kerukunan antar umat beragama secara bottom $u p^{91}$.

Wadah yang sudah ada tersebut dapat memfasilitasi para pemuka agama yang menjadi panutan masyarakat dengan kegiatan bermusyawarah untuk membahas berbagai persoalan keagamaan dan upaya-upaya yang ditempuh bersama mencari solusi memecahkan persoalan. Juga dapat dilakukan dialog antara pemuka agama dengan masyarakat sehingga dapat menampung dan menyalurkan aspirasi masyarakat tingkat grass root. Tugas para pemuka agama adalah menyampaikan kepada umat masing-masing mengenai tradisi dialog ini ${ }^{92}$. Fokus utama tujuan dari terbentuknya wadah ini adalah terciptanya hubungan antar agama dan kepercayaan di negeri ini secara harmonis, terhindarkan dari ketegangan, kecurigaan, dan kekerasan ${ }^{93}$.

Di wadah kerukunan umat beragama inilah, salah satu jalan untuk mensosialisasikan konsep pendidikan multikultural. Wadah ini dipandang efektif untuk mensosialisasikan konsep pendidikan multikultural, karena wadah ini presentasi dari para pemuka tokoh beragama dan bahkan bisa dihadiri oleh perwakilan dari masyarakat bawah. Para pemuka agama merupakan tokoh dari perwakilan masing-masing agama yang dipandang oleh mereka (penganut agama masing-masing) sebagai simbol. Mereka bisa menyampaikan ide-ide cemerlang yang mereka peroleh untuk disampaikan kepada para penganutnya masingmasing. Sehingga ide-ide pendidikan multikultural ini bisa sampai kepada masyarakat secara menyeluruh, baik dari kalangan bawah maupun kalangan elit.

Pendidikan multikultural ini diharapkan dapat mengharmonisasikan segala perbedaan kebudayaan yang ada, sehingga tercipta kehidupan yang aman, tenteram serta damai dalam satu bingkai Negara Kesatuan Republik Indonesia yang kita cintai.

\subsection{Kendala dialog}

91 Ibid.

92 Sambutan Menteri Agama RI dalam Buku Peraturan Bersama Menteri Agama dan Menteri Dalam Negeri No 9 dan 8 Tahun 2006 tentang Pedoman Pelaksanaan Tugas Kepala Daerah/Wakil Kepala Daerah dalam Pemeliharaan Kerukunan Umat Beragama, Pemberdayaan Forum Kerukunan Umat Beragama dan Pendirian Rumat Ibadat, Balitbang Dep. Agama RI, 2006, hal. 10. ${ }^{93}$ Endang Turmudzi, "Masalah Kerukunan Umat Beragama." 
Di antara kendala dialog adalah; pertama, wacana dialog hanya di tingkat elit; kedua, kualitas dan kuantitas aktivis dialog tidak mampu menjawab tuntutan umat; ketiga, sarana/wadah penunjang dialog hingga ke level bawah sangat terbatas; keempat, prasangka buruk pada umat lain; kelima, da’i yang kurang memahami dialog menguasai jalur sosialisasi ajaran agama hingga akar rumput; keenam, ketidak adilan dan kesenjangan sosial; ketujuh, konflik golongan internal agama ${ }^{94}$. Namun, al-Qur'an berpesan melalui Surat Ali Imran ayat 103 yang artinya:

"Dan berpegang teguhlah kamu semuanya kepada tali (agama) Allah, dan janganlah kamu bercerai berai. Ingatlah nikmat Allah kepadamu ketika kamu dahulu (masa Jahiliyah) bermusuhan, lalu Allah mempersatukan hatimu, sehingga dengan karunia-Nya kamu menjadi bersaudara, sedangkan (ketika itu) kamu berada di tepi jurang neraka, lalu Allah menyelamatkan kamu dari sana. Demikianlah, Allah menerangkan ayat-ayat-Nya kepadamu, agar kamu mendapat petunjuk".

Allah menunjukkan dan memberikan nikmat besar berupa nikmat beragama Islam, mengikuti Rasulullah shallallahu 'alaihi wa sallam serta bersatunya kaum muslimin dan tidak berpecah belah ${ }^{95}$. Allah menginginkan kita untuk bersatu dan tidak bercerai berai, karena permusuhan akan membentangkan jalan kepada neraka. Pun dengan kelompok dan golongan non muslim, kita harus saling menjaga untuk tidak saling bermusuhan.

\section{Kesimpulan}

Keragaman budaya di Indonesia merupakan keniscayaan yang mempersatukan semua elemen negara. Namun, keragaman budaya dapat juga memicu gesekan yang menimbulkan konflik antar golongan. Di sinilah perlu adanya terobosan yang bisa mengikis segala persoalan yang bisa menimbulkan pelbagai kasus tersebut, diantaranya adalah terobosan pendidikan multikultural. Pendidikan multikultural dipandang penting untuk mengubah paradigma seseorang bahkan masyarakat yang monokultural menjadi multikultural,

${ }^{94}$ Achmad Rosyidi, "Penguatan Integritas Bangsa Melalui Internalisasi Ajaran Agama."

${ }^{95}$ Musa, Tafsir Al Qur'an Hidayatul Insan Jilid I. h. 189 
ISSN : 2656-3134 (Online) - 2338-3801 (Print)

Pendidikan multikultural disampaikan dan dimusyawarahkan dengan antar umat beragama (non muslim).

Dari segi istilah Pendidikan adalah proses pengubahan sikap dan tata laku seseorang atau kelompok orang dalam usaha mendewasakan manusia melalui upaya pengajaran dan pelatihan agar peserta didik secara aktif dapat mengembangkan potensi dirinya untuk memiliki kekuatan spiritual keagamaan, pengendalian diri, kepribadian, kecerdasan, akhlak mulia, serta keterampilan yang diperlukan dirinya dan masyarakat. Sedangkan pendidikan multikultural adalah seperangkat strategi dan bahan yang dikembangkan untuk membantu para guru dalam pendidikan dengan pendekatan progresif untuk mengubah pendidikan secara menyeluruh sekaligus merespon praktek kebijakan dan kurikulum yang diskriminasi dalam pendidikan.

Ide-ide pendidikan multikultural selain diinternalisasikan dalam dunia pendidikan, seharusnya juga disosialisasikan dalam dialog antar umat beragama yakni FKUB. FKUB merupakan forum yang diwakili dari seluruh komponen kelompok dan golongan, forum ini dipandang efektif dan efisien untuk menyampaikan ide-ide pendidikan multikultural karena keterwakilan dari berbagai kelompok dan golongan tersebut. Penyampaian ide-ide pendidikan multikultural disampaikan dengan pola komunikasi yang diajarkan dalam al-Qur'an.

Islam melalui al Qur'an mengajarkan komunikasi yakni dengan qaulan ma'rufan, berbicara dengan kata-kata yang lembut. Kedua qaulan sadiidan yaitu berbicara dengan tutur kata yang benar. Ketiga qaulan balighan, yaitu menasehati secara rahasia dan menasehati dengan kata-kata yang bisa membekas di hatinya. Keempat, qaulan kariman Yakni berkata yang menenteramkan hati yang disesuaikan dengan keadaan, kebiasaan dan zaman. Kelima qaulan maysuuran yaitu perkataan yang baik agar tidak mengecewakan karena belum mendapat yang diharapkan. Keenam qaulan layyinan yaitu perkataan yang lembut dan beradab, tidak membual (mengada-ada), tidak keras ucapannya dan tidak kasar sikapnya. 


\section{DAFTAR PUSTAKA}

Abd A'la. "Pembumian Jihad Dalam Konteks Indonesia Kekinian, Pengentasan Masyarakat Dari Kemiskinan Dan Keterelakangan.” Harmoni 8 (2009).

Abdul Munir Mulkhan. Kesalehan Multikultural. Jakarta: Pusat Studi Agama dan Peradaban (PSAP) Muhammadiyah, 2005.

Abdullah Bin Muhammad Bin Abdurrahman Bin Ishaq al Syeikh. "Terjemah Tafsir Ibnu Katsir." In 4, edited by M. Yusuf Harun MA Dkk, 466. I. Bogor: Pustaka Imam asy Syafi'i, 2003.

Achmad Rosyidi. "Penguatan Integritas Bangsa Melalui Internalisasi Ajaran Agama." Harmoni 8 (2009): 29.

Ali, H Mursyid. Pemetaan Kehidupan Beragama Di Berbagai Daerah Di Indonesia. I. Jakarta: CV. Prasasti, 2009.

Al-Sheikh, Abdullah bin Muhammad bin Abdurahman bin Ishaq. Tafsir Ibnu Katsir Jilid 5. Edited by M. Yusuf Harun MA. I. Bogor: Pustaka Imam asy Syafi'i, 2003.

Arifin, Akhmad Hidayatullah Al. "Implementasi Pendidikan Multikultural Dalam Praksis Pendidikan Di Indonesia.” Jurnal Pembangunan Pendidikan: Fondasi dan Aplikasi 1, no. 1 (2012): 72-82.

Azhar, Subhi. "Rethinking Dialogue: Antara Konflik Dan Perubahan Damai." Harmoni 10 (2011).

Banks, James a. "Multicultural Education: Historical Development, Dimensions, and Practice." JSTOR (1993): 3-14.

Banks, James A. Banks and Cherry A. McGee. "Multicultural Education Issues and Perspectives. 3rd Ed. Needham Heights, MA: Allyn and Bacon." Connecticut State Department of Education. Last modified 1997. ttp://www.sde.ct.gov/sde/cwp/view.asp?a.

Burhan Bungin. Metodologi Penelitian Kualitatif Aktualisasi Ragam Varian Kontemporer. Jakarta: PT. Rajagrafindo Persada, 2007. 
Endang Turmudzi. “Masalah Kerukunan Umat Beragama.” Harmoni 10 (2011): 516.

Farida Hanum dan Sisca Rahmadona. "Implementasi Model Pembelajaran Multikultural Di Sekolah Dasar Di Propinsi Daerah Istimewa Yogyakarta.” Artikel Multikultural-Stranas, no. 2 (2009): 1-17.

Fauziyah. "Potret Kerukunan Hidup Umat Beragama Di Kabupaten Bondowoso Jawa Timur." Harmoni 2011 (n.d.).

Ford, Donna Y. "Why Education Must Be Multicultural: Addressing a Few Misperceptions With Counterarguments ." Gifted Child Today 37 , no. 1 (2014): 59-62. http://gct.sagepub.com/cgi/content/abstract/37/1/59.

H. Haidlor Ali Ahmad. Revitalisasi Wadah Kerukunan Umat Beragama. Edited by H. Haidlor Ali Ahmad. I. Jakarta: CV. PRASASTI, 2009.

Hasan Basri Tanjung. "Bertutur Kata.” Khazanah Republika, April 2015.

Ibnu Hasan Muchtar. "Dinamika Hubungan Antarumat Beragama Di Kota Dan Kabupaten Jayapura Papua.” Harmoni 10 (2011): 627.

Ikhwan. "Pengadilan HAM: Penyelesaian Kasus Pelanggaran HAM Di Masa Rasulullah SAW." Harmoni 8 (2009).

KHQ Shaleh dkk. "Asbabun Nuzul Surat Al Mumtahanah.” Http:/ / www.tafsironline.org.

M Quraish Shihab. Wawasan Al Qur'an Tafsir Maudbu'i Atas Pelbagai Persoalan Umat. Jakarta: Mizan, 1996.

Muchlis M. Hanafi. “Kosep Al-Wasathiyyah Dalam Islam.” Harmoni 8 (2009): 51.

Muhaimin (ed.). Damai Di Dunia Damai Untuk Semua; Perspektif Berbagai Agama, Bunga Rampai. Jakarta: Puslitbang Kehidupan Beragama Balitbang Dep. Agama, 2004.

Musa, Abu Yahya Marwan Bin. Tafsir Al Qur'an Hidayatul Insan Jilid I. www.tafsir.web.id, n.d.

—. Tafsir Al Qur'an Hidayatul Insan Jilid II. www.tafsir.web.id, n.d. 
SN : 2656-3134 (Online) - 2338-3801 (Print)

_. “Tafsir Al Qur’an Hidayatul Insan Jilid III.” www.tafsir.web.id, n.d.

Tafsir Al Qur'an Hidayatul Insan Jilid IV. www.tafsir.web.id, n.d.

Nafan Akhun. AL QUR'AN Digital 2.1. http://www.alqur'an-digital.com, 2007.

Paul C. Gorski. “A Working Definition of Multicultural Education.” http://www.edchange.org, 2015.

Puslitbang Kehidupan Keagamaan Departemen Agama RI. "Dinamika Beragama Dalam Pergumulan Sosial Budaya." Harmoni X, no. 1 (2011): 1-740.

Rusdi Muchtar. "Peran Jihad Dalam Menanamkan Nilai-Nilai Keagamaan” 8 (2009): 10.

Sayyid Quthub. “Terjemah Tafsir Fi Zhilalil Qur'an XI.” In Juz XXVIII: AlMujadalah S.d. at-Tahrim, 238, n.d.

Suhardi, Didik. "Peran SMP Berbasis Pesantren Sebagai Upaya Penanaman Pendidikan Karakter Kepada Generasi Bangsa.” Jurnal Pendidikan Karakter 3 (2012): 316-328.

Tasnim Muhammad, dkk. "Implementasi Nilai-Nilai Multikultural Dalam Pendidikan Di Program Studi Pendidikan Bahasa Arab (PBA) Fakultas Tarbiyah Dan Bahasa IAIN Surakarta.” JLAH 2 (2013).

Tim Penyusun Kamus Bahasa Indonesia. Kamus Besar Bahasa Indonesia. Jakarta: Pusat Bahasa Departemen Pendidikan Nasional, 2008.

Winarno Surachman. Pengantar Penelitian Ilmiah: Dasar, Metode. Tarsita, 1990. www.wikipedia.org. "Multicultural Education" (2016): 1-10.

Zuriah, Nurul. "Model Pengembangan Pendidikan Kewarganegaraan Multikultural Berbasis Kearifan Lokal Dalam Fenomena Sosial Pasca Reformasi Di Perguruan Tinggi." Jurnal Penelitian Pendidikan 12 (2011): 63-72. 